\title{
Physicochemical and Sorption Properties of Anionites Based on Aromatic Amines, Epichlorohydrin and Polyethylenimine with Regard to Strontium (II) Ions
}

\author{
Edil Ergozhin, Tulegen Chalov, Tatyana Kovrigina, Yevgeniy Melnikov* \\ A.B. Bekturov Institute of Chemical Sciences, 106 Sh. Ualikhanov Str., Almaty, 050010, Republic of Kazakhstan
}

Received: $27 / 06 / 2020$

Accepted: 27/09/2020

Published: 20/12/2020

\begin{abstract}
Multifunctional anion exchangers based on aromatic amines, epichlorohydrin and polyethylenimine have been synthesized. Their composition, structure, and thermal stability have been studied using IR spectroscopy, elemental and thermogravimetric analyses. Extraction of strontium ions has been studied using classical polarography, and sorption of strontium (II) ions in static regime has been determined as a function of solution acidity, metal ion concentration, and contact duration of ionites with $\mathrm{SrCl}_{2}$ solution. It has been established that the obtained ion exchangers are characterized by high sorption properties with regard to strontium ions. The novelty of these studies is that the sorption dependence of synthesized ionites with regard to $\mathrm{Sr}^{2+}$ ions has been studied for the first time. The practical importance of this work is the development of anion exchangers with higher extractability, which could successfully solve the issues of elimination of strontium (II) ions from process wastes of nonferrous metallurgy.
\end{abstract}

Keywords: Sorption, Strontium, Sorption capacity, Anion exchanger, Extraction

\section{Introduction}

Development of nuclear power engineering and accompanying industries results in contamination of environmental objects by radioactive metal ions, which poses a health risk, since long-living radionuclides tend to accumulation, can easily be transferred to high distances and quite often participate in the biological cycle [1]. In this regard it is very important to develop efficient sorbents produced by simple and inexpensive process as well as characterized by high capacity and selectivity with regard to extracted cations and reliably holding radionuclides extracted from contaminated solutions in the form suitable for long-term storage, processing, or disposal [2].

Strontium is one of the main contaminants of radioactive waste waters widely occurring in nuclear fuel, medicinal and industrial radioactive wastes $[3,4]$. It is well known that strontium is characterized by long half-life, high solubility, and high bioaccessibility. After penetration with contaminated food into organism strontium will accumulate in bones and marrow, which can cause cancer of adjacent tissues and leukemia. Therefore, systematic and efficient methods of elimination are especially important to provide steady development of humans and environmental protection [3-6].

Sorption is one of the most efficient approaches to treatment of wastes with heavy metals due to its low cost, high efficiency and readily recovered sorbents [7]. A significant number of publications are devoted to studying the features of separation and extraction of strontium and its purification from the impurities using anionites of various structure [3, 8-10]. In [3], the authors studied the sorption capacity of new adsorbent obtained from almonds in relation to strontium ions, where the sorption capacity (SC) reached $11.45 \mathrm{mg}^{-g^{-1}}$ at $\mathrm{pH}=10.8$. At strontium concentration of $20 \mathrm{mg} \cdot \mathrm{l}^{-1}$ and $\mathrm{pH}=7.0 \pm 0.1$ of the solution, the $\mathrm{SC}$ values of the modified ion exchangers approached the value of $1.6 \mathrm{mg} \cdot \mathrm{g}^{-1}$ [4]. In [5], the authors analyzed the environmental conditions impact on the sorption behavior of $\mathrm{Sr}$ (II) and identified that the $\mathrm{Sr}$ (II) sorption was greatly affected by ionic strength at $\mathrm{pH}<9.5$, and no effect at $\mathrm{pH}>9.5$ was found. This fact indicated that in the mechanism of $\mathrm{Sr}$ (II) sorption, outer-sphere surface complexation or ion exchange at low $\mathrm{pH}$ prevailed; at $\mathrm{pH}$ $=7.0 \pm 0.1$ and $\mathrm{csr}_{\mathrm{Sr}}=15 \mathrm{mg} \cdot \mathrm{l}^{-1}$, the $\mathrm{SC}$ value reached $20 \mathrm{mg} \cdot \mathrm{g}^{-1}$. In [6], the authors found that the $\mathrm{SC}$ of complexing polymeric sorbents based on EDE-10P and chlorine-containing quinones was $358.2-420.4 \mathrm{mg} \cdot \mathrm{g}^{-1}$ at $\mathrm{pH}=4.6, \mathrm{csr}_{\mathrm{Sr}}=1.926 \mathrm{mg} \cdot \mathrm{l}^{-1}$. Thus, in [8] it was established that maximum $S C$ of polymer complexing sorbents of various structure with regard to strontium ions was 50 $\mathrm{mg} \cdot \mathrm{g}^{-1}$ at $\mathrm{pH}$ of solution from 2.2 to 7.0 . Thus, certain interest is attracted to analysis of strontium ions sorption on specially produced anionites characterized by high SC and containing

Corresponding author: Yevgeniy Melnikov, A.B. Bekturov Institute of Chemical Sciences, 106 Sh. Ualikhanov Str., Almaty, 050010, Republic of Kazakhstan. E-mail: sebas273@mail.ru 
active groups in their structure. This work is aimed at analysis of physicochemical and sorption properties of multifunctional anionites based on epoxy derivatives of aromatic amines and polyethylenimine with regard to strontium (II) ions.

\section{Methods}

On the basis of aniline (A) or benzylamine (BA) and epichlorohydrin $(\mathrm{ECH})$ we synthesized epoxy amines, and then, by condnesing them with polyethylenimine (PEI), multifuctional anionites A-ECH-PEI and BA-ECH-PEI [11]. At first, using A or BA and $\mathrm{ECH}$ in the presence of caustic soda at $50^{\circ} \mathrm{C}$ for $6 \mathrm{~h}$, glycidyl derivatives of amines (epoxy amines) were synthesized. Then, their polycondensation with PEI was carried out in dimethylformamide (DMFA) solution at various ratios, $60-65^{\circ} \mathrm{C}$ for 5-6 h, then the reacted mass was solidified at $100^{\circ} \mathrm{C}$ for $16-$ $24 \mathrm{~h}$. Composition and chemical structure of the anionites were analyzed by IR spectroscopy using a Nicolet 5700 Fourier spectrometer (Thermo Electron Corporation, USA) and by elemental analysis using a CHN628 instrument (LECO, USA). As can be seen in Fig. 1, $a, b$, the IR spectra of A-ECH-PEI and BA-ECH-PEI anionites are very similar, which probably could be attributed to close chemical structure. These spectra do not contain characteristic bands $\left(\mathrm{cm}^{-1}\right)$ of epoxy groups (810-920; $1,250 ; 3,000-3,010)$, there appear bands of $\mathrm{N}-\mathrm{H}$ bending vibrations $(1,599-1,600)$ and $\mathrm{C}-\mathrm{N}$ stretching vibrations $(1,020$ $1,220)$ of amine group bonds, which evidences chemical interaction of diglycidyl derivatives of A and BA with PEI. The frequency at 3,500 characterizes occurrence of hydroxyl groups. Absorption in the 1,502-1,504 area, stipulated by stretching vibrations of benzene ring, confirms existence of aromatic fragments in the anionite structure [12]. The elemental composition of anionites (detected/predicted), \% for A-ECHPEI: C - 73.32/73.86; H - 17.60/17.34; N - 5.89/5.60; O 3.19/3.20; and for BA-ECH-PEI: C - 70.72/70.92; H 17.61/17.48; $\mathrm{N}-7.81 / 8.09$; O - 3.86/3.51. On the basis of chemical and spectral analyses, the structure of synthesized polymers can be presented as follows (Figure 2):
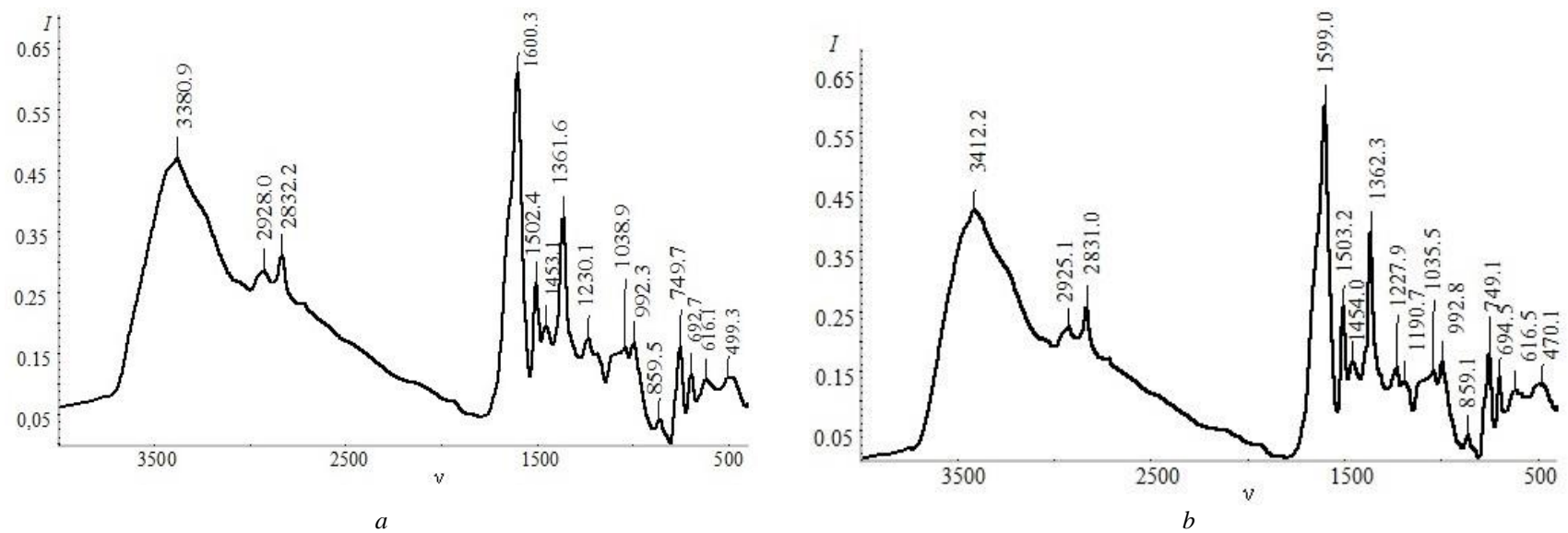

Figure 1: IR spectra of BA-ECH-PEI $(a)$ and A-ECH-PEI $(b) . I$ - intensity, $v$ - wave number $\left(\mathrm{cm}^{-1}\right)$<smiles>CN1CCNCCN(C)CC(O)CN(CC(O)O)c2ccccc2CN(c2ccccc2)CC(O)CN(C)CCN(C)CC(O)C1</smiles>

A-ECH-PEI

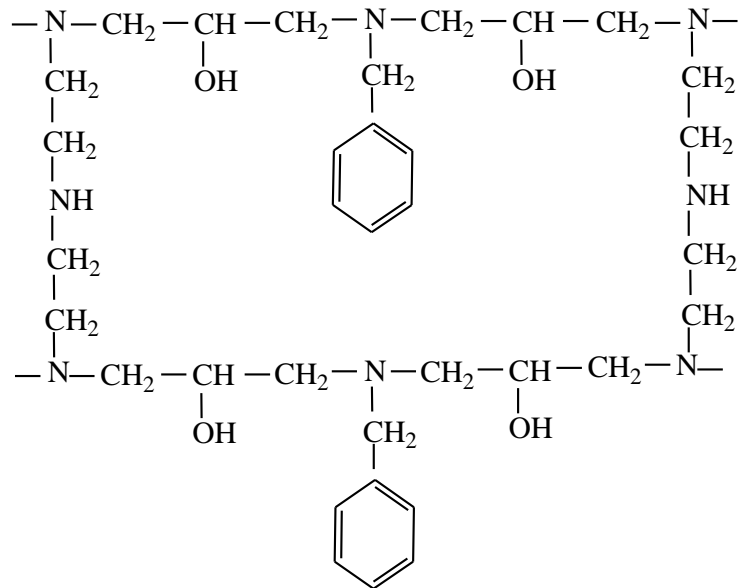

BA-ECH-PEI

Figure 2: Structures of synthesized polymers 
The morphology and chemical structure of polymer matrix, as well as the structure of surface of the given anionites are similar to that studied previously and described in [13]. Thermal resistance of anionites in $\mathrm{OH}$ form was studied by thermogravimetric analysis (TGA). Thermograms were obtained using TGA/DSC1 thermogravimetric analyzer (Mettler Toledo, Switzerland) in air in the range of $20-600^{\circ} \mathrm{C}$ at heating rate of $10^{\circ} \mathrm{C} / \mathrm{min}$. In order to determine static exchange capacity (SEC) of anionites using $0.1 \mathrm{~N} \mathrm{HCl}$ solution, a sample of anionite in the $\mathrm{OH}$ from in the amount of $1 \mathrm{~g}$ on dry basis measured with the accuracy of $0.0002 \mathrm{~g}$ was poured with $100 \mathrm{ml}$ of $0.1 \mathrm{~N}$ titrated solution of hydrochloric acid in $250 \mathrm{ml}$ flat bottom flask and sealed. Reaching equilibrium ( $24 \mathrm{~h}), 25 \mathrm{ml}$ of filtrate was titrated by $0.1 \mathrm{~N}$ solution of sodium hydroxide in the presence of three droplets of methyl red until pink color changed into yellow. The concentration of functional groups in polymer phase corresponding to the ionite $S E C$ (mg-eq. $\mathrm{g}^{-1}$ ) was calculated as follows: $\mathrm{SEC}=(100-4 \mathrm{~V}) / 10 \mathrm{P}$, where $V$ was the exact volume of $0.1 \mathrm{~N}$ solution of sodium hydroxide consumed for titration $(\mathrm{ml})$; $P$ was the ionite sample on dry basis (g). In order to determine the volume occupied by mass unit of dry ionite after swelling in water, a sample of about $10 \mathrm{~g}$ was placed into cylinder and poured with $70 \mathrm{ml}$ of water. The cylinder was tightly sealed and agitated up to complete wetting of lower layers of ionite and held in horizontal position for $12 \mathrm{~h}$. Then the cylinder was positioned vertically, water was refilled to $100 \mathrm{ml}$, and compacted to constant volume by tapping cylinder bottom against wooden surface. After the compaction, the volume occupied by ionite was measured. The specific volume of swelled ionite $\left(V_{s p}, \mathrm{ml} \cdot \mathrm{g}^{-1}\right)$ was determined as follows: $\mathrm{V}_{\mathrm{sp} .}=\mathrm{V} / \mathrm{G}$, where $V$ was the volume of swelled ionite, $\mathrm{ml} ; G$ was the sample of dry ionite, $\mathrm{g}$.

In order to determine chemical resistance of the ionites with regard to solutions of acids and alkalis, two ionite samples, $0.1 \mathrm{~g}$ on dry basis each, were placed into $250 \mathrm{ml}$ round bottom reflux flask. One sample was poured with $100 \mathrm{ml}$ of $5 \mathrm{~N}$ solution of sulfuric acid, the other sample was poured with $100 \mathrm{ml}$ of $5 \mathrm{~N}$ solution of sodium hydroxide. The content of the flasks was held for $30 \mathrm{~min}$ on boiling water bath. Then the mixture was cooled in air to ambient temperature and the ionite was separated by filtration. The anionite was converted into hydroxyl form when required. The ionites were washed in distilled water, their $S E C$ was determined. Chemical resistance $(C R, \%)$ of the ionites was determined by the ratio of the obtained exchange capacity to the initial one: $\mathrm{CR}=\mathrm{SEC} / \mathrm{SEC}_{0} * 100$, where $S E C_{0}$ and $S E C$ were the static exchange capacity of ionites before and after processing with acid or alkali, respectively. In order to determine the ionite $C R$ with regard to oxidizing solutions, a sample of ionite $(1 \mathrm{~g})$ was poured with $100 \mathrm{ml}$ of $10 \%$ solution of hydrogen peroxide, held at ambient temperature for $48 \mathrm{~h}$ with periodic stirring. The ionite was separated by filtration, converted into hydroxyl form, washed in distilled water, the $S E C$ was determined. The ionite resistance was determined using the previous equation.

Sorption of strontium (II) ions by A-ECH-PEI and BA$\mathrm{ECH}-\mathrm{PEI}$ in $\mathrm{OH}$ form was analyzed under static conditions at sorbent:solution ratio equaling to $1: 400,20 \pm 2^{\circ} \mathrm{C}$, varying the concentration of strontium ions in $\mathrm{SrCl}_{2}$ solutions from 0.184 to $2.015 \mathrm{~g} \cdot \mathrm{l}^{-1}$ and varying their acidity by addition of $5 \mathrm{~N} \mathrm{HCl}$ solution in the $\mathrm{pH}$ range from 1.0 to 6.3 . $\mathrm{pH}$ was measured using $\mathrm{pH}-150 \mathrm{MI}$ meter with the measurement error of $\pm 0.05 \mathrm{pH}$ units.
The contact duration of sorbents with solutions was from $0.5 \mathrm{~h}$ to 7 days. The model solutions were prepared using $\mathrm{SrCl}_{2} * 6 \mathrm{H}_{2} \mathrm{O}$, reagent grade. The $S C$ was calculated by the difference between initial and equilibrium concentration of solutions, determined by classical polarography against $0.5 \mathrm{M} \mathrm{LiCl}$ by the reduction wave $\mathrm{Sr}^{2+}\left(\mathrm{E}_{1 / 2}=-2.03 \mathrm{~V}\right)$. Polarograms were recorded using a PU-1 universal polarograph with the measurement error of $\pm 0.5 \%$ in thermostatic cell at $25 \pm 0.5^{\circ} \mathrm{C}$ using dropping mercury electrode. Oxygen was removed from the analyzed solution by purging argon for $5 \mathrm{~min}$. Saturated calomel electrode was used as reference. The modes of sorption experiments were selected (sorbent-to-solution ratio, concentration and $\mathrm{pH}$ of strontium containing model solutions, and contact duration) being close to commercial conditions.

\section{Results and discussion}

Practical application of ionites requires for analysis of their physicochemical properties as well as of sorption of metal ions depending on process conditions. Aiming at determination of optimum sorption parameters, the influence of concertation and $\mathrm{pH}$ of $\mathrm{SrCl}_{2}$ solutions as well as the contact duration on the extraction of strontium (II) ions was studied. Table 1 summarizes the main physicochemical properties of the synthesized anionites determined according to the procedures in $[14,15]$.

Table 1: Main physicochemical properties of the synthesized anionites

\begin{tabular}{|l|l|l|l|l|l|}
\hline \multirow{2}{*}{$\begin{array}{l}\text { Anionites } \\
\text { based on }\end{array}$} & \multirow{2}{*}{$\begin{array}{l}\mathrm{SEC}_{\mathrm{HCl}}, \\
\mathrm{mg} \mathrm{eq} \cdot \mathrm{g}^{-1}\end{array}$} & \multirow{2}{*}{$\begin{array}{l}\mathrm{V}_{\mathrm{sp}}, \\
\mathrm{ml} \cdot \mathrm{g}^{-1}\end{array}$} & \multicolumn{3}{|l|}{$\begin{array}{l}\text { Chemical resistance in } \\
\text { solutions, \% }\end{array}$} \\
\cline { 4 - 6 } & $\begin{array}{l}5 \mathrm{~N} \\
\mathrm{H}_{2} \mathrm{SO}_{4}\end{array}$ & $\begin{array}{l}5 \mathrm{~N} \\
\mathrm{NaOH}\end{array}$ & $\begin{array}{l}10 \% \\
\mathrm{H}_{2} \mathrm{O}_{2}\end{array}$ \\
\hline $\begin{array}{l}\text { A-ECH- } \\
\text { PEI }\end{array}$ & 4.83 & 4.5 & 92.5 & 94.9 & 70.1 \\
\hline $\begin{array}{l}\text { BA-ECH- } \\
\text { PEI }\end{array}$ & 8.95 & 5.7 & 97.9 & 98.7 & 72.0 \\
\hline
\end{tabular}

Stringent requirements to thermal resistance are set to ion exchangers intended for long-term operation at higher temperatures [16]. The thermal resistance is an important property of polymer materials allowing to detect destruction processes at higher temperatures, leading to impairment of operational properties and environmental pollutions. Destruction of ionites in dry state allows better estimation of the thermal stability of matrix and ionogenic groups and determination of initial temperatures of destruction of these structural elements. Thermograms of AECH-PEI and BA-ECH-PEI are illustrated in Figure 3. The use of $T G A$ allows to determine the weight loss of ionite during thermal destruction. The results of TGA of anionites based on epoxy derivatives of aromatic amines and polyethylenimine are summarized in Table 2. The TGA curves (Fig. 1, $a, b$ ), the shapes of which are identical, illustrate that the initial temperature of their destruction, after which the weight loss is significant, is $260^{\circ} \mathrm{C}$ for A-ECH-PEI and $280^{\circ} \mathrm{C}$ for BA-ECH-PEI. These temperatures on the curves of differential scanning calorimetry correspond to occurrence of exothermal maximums, which can be probably attributed to heat evolution upon further structuring of ionites, then the polymer matrix is destructed. Herewith, their weight loss is $8 \%$. The commercial sorbent EDE-10p upon heating to $100-200^{\circ} \mathrm{C}$ loses more than $20 \%$ of its weight [17]. 


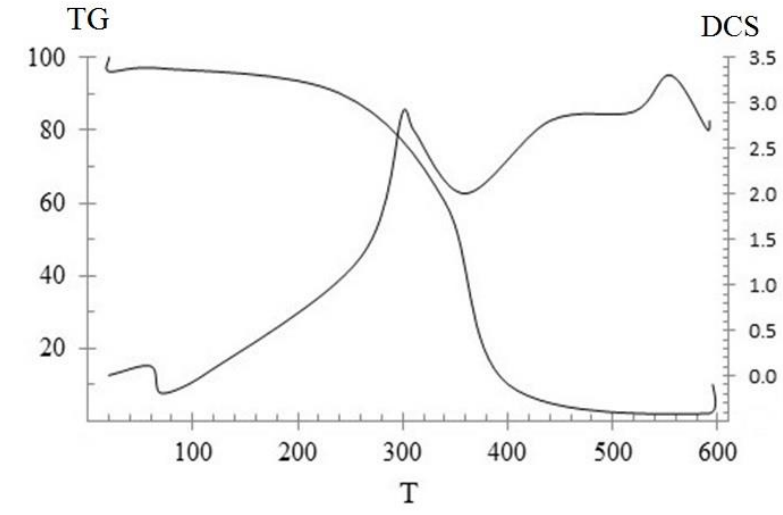

a) - (On the left there is a TG curve from top to bottom, and on the right DSC curve)

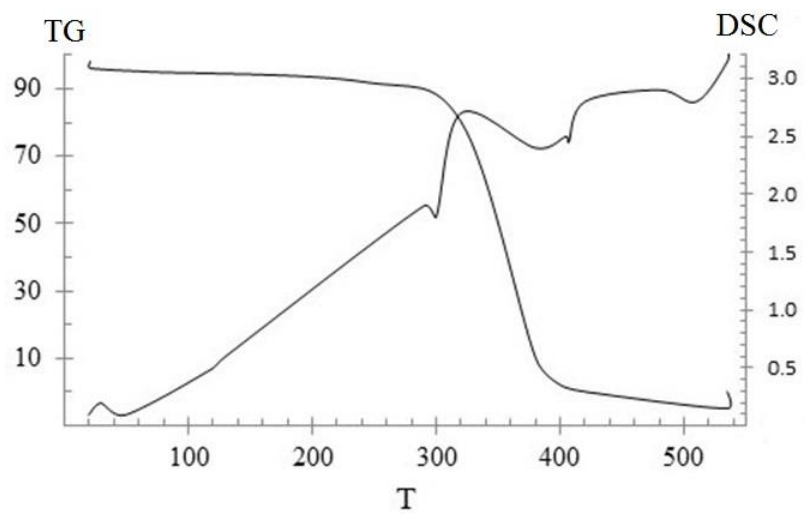

b) - (On the left there is a TG curve from top to bottom, and on the right DSC curve)

Figure 3: Thermogravimetric analysis of anionites based on A-ECH-PEI $(a)$ and BA-ECH-PEI $(b) . T$ is the temperature $\left({ }^{\circ} \mathrm{C}\right), D S C$ is the thermal capacity dependence $\left(\mathrm{J} \cdot 10^{3} \cdot \mathrm{mg}^{-1}\right), T G$ is the weight loss $(\%)$

Table 2: Weight loss of A-ECH-PEI and BA-ECH-PEI at various temperatures

\begin{tabular}{|c|c|c|}
\hline \multirow{2}{*}{$\mathrm{T},{ }^{\circ} \mathrm{C}$} & \multicolumn{2}{|c|}{ Weight loss, \% } \\
\cline { 2 - 3 } & A-ECH-PEI & BA-ECH-PEI \\
\hline 100 & 5 & 5 \\
\hline 200 & 8 & 8 \\
\hline 300 & 20 & 15 \\
\hline 350 & 55 & 40 \\
\hline 400 & 90 & 95 \\
\hline
\end{tabular}

It has been established that these anion exchangers are characterized by sufficiently high thermal resistance. The structure of their polymer matrix exerts significant effect on thermal stability of anionites, which at $300-350^{\circ} \mathrm{C}$ decreases as follows: A-ECH-PEI > BA-ECH-PEI

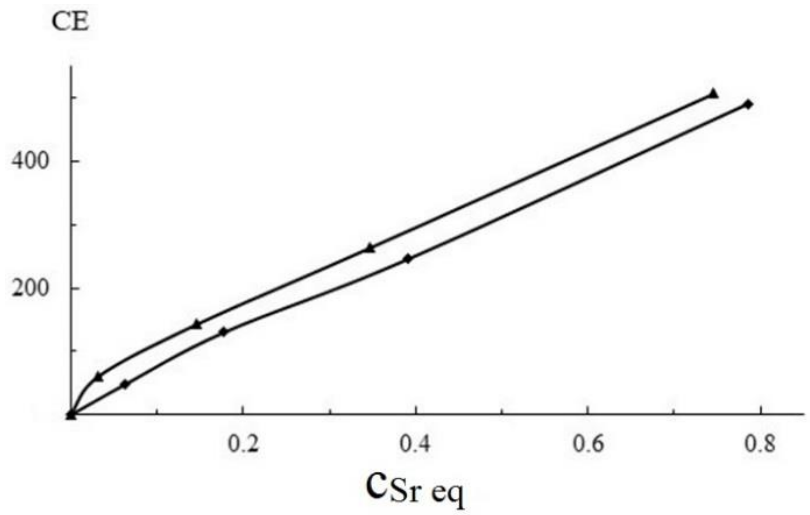

Figure 4: Sorption isotherms of $\mathrm{Sr}^{2+}$ ions by A-ECH-PEI (1) and BA$\mathrm{ECH}-\mathrm{PEI}$ (2). Duration of contact is 7 days; $\mathrm{pH}=1.0 ; \mathrm{c}_{\mathrm{eq}}$ is the equilibrium concentration; $\mathrm{SC}$ is the sorption capacity $\left(\mathrm{mg} \cdot \mathrm{g}^{-1}\right), \mathrm{c}_{\mathrm{Sr} \text { eq }}$ is the equilibrium concentration $\left(\mathrm{g} \cdot \mathrm{l}^{-1}\right)$

It can be seen in Figure 3 illustrating the sorption isotherms of $\mathrm{Sr}^{2+}$ ions that the anionite $\mathrm{SC}$ increases with the content of strontium ions in solutions. The curve rising at low equilibrium concentrations evidences that these anionites extract strontium (II) ions with sufficient completeness. Herewith, the extraction rate reaches $83 \%$. The sorption capacity of BA-ECH-PEI upon extration of $\mathrm{Sr}^{2+}$ ions is higher in comparison with A-ECH-PEI, their SC is $507.7 \mathrm{mg} \cdot \mathrm{g}^{-1}$ and $491.36 \mathrm{mg} \cdot \mathrm{g}^{-1}$, respectively. One of the main factors upon extraction of metal ions from solution is the medium acidity, which influences both the form of the considered ion in solution, and the state of ionogenic groups [11]. It can be seen in Fig. 5 illustrating sorption capacity of anionites with regard to lead ions as a function of acidity of $\mathrm{SrCl}_{2}$ solutions that the optimum $\mathrm{pH}$ for their extraction is 1.0. Under such conditions, the absorption of strontium (II) ions is maximum.

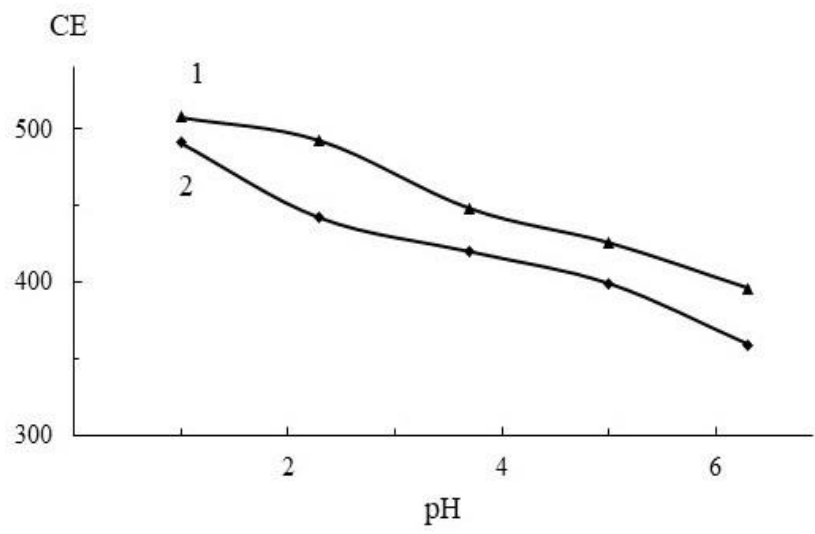

Figure 5: Sorption of $\mathrm{Sr}^{2+}$ ions by A-ECH-PEI (1) and BA-ECH-PEI (2) as a funciton of acidity of $\mathrm{SrCl}_{2}$ solution; $\mathrm{c} \mathrm{sr}_{\mathrm{Sr}}=2.015 \mathrm{~g} \cdot \mathrm{l}^{-1}$, duration of contact: 7 days

It also follows from Figure 5 that the sorption capacity of ionites is determined mainly by the ionic state of strontium in the solution. The acidity range corresponding to maximum $S C$, is stipulated, on the one hand, by the ratio of the interaction energy of metal cations and hydrogen with active polymer centers, and on the other hand, by $\mathrm{pH}$ values determining the started formation of hydroxide deposits and main metal salts. Further decrease in the solution acidity leads to deposition of strontium hydroxide. The mentioned facts evidence the necessity to achieve certain $\mathrm{pH}$ of acidity of purified water. Figure 6 illustrates the isotherms of sorption of strontium (II) ions by BA-ECH-PEI and A-ECHPEI. Equilibrium state between the ionites and the solution 
containing $2.015 \mathrm{~g} \cdot \mathrm{l}^{-1}$ strontium and having $\mathrm{pH} 1.0$ is reached for BA-ECH-PEI in $1 \mathrm{~h}$, and for A-ECH-PEI - in $3 \mathrm{~h}$. Herewith, the $S C$ of BA-ECH-PEI is 507.7, and of A-ECH-PEI is 491.36 $\mathrm{mg} \cdot \mathrm{g}^{-1}$.

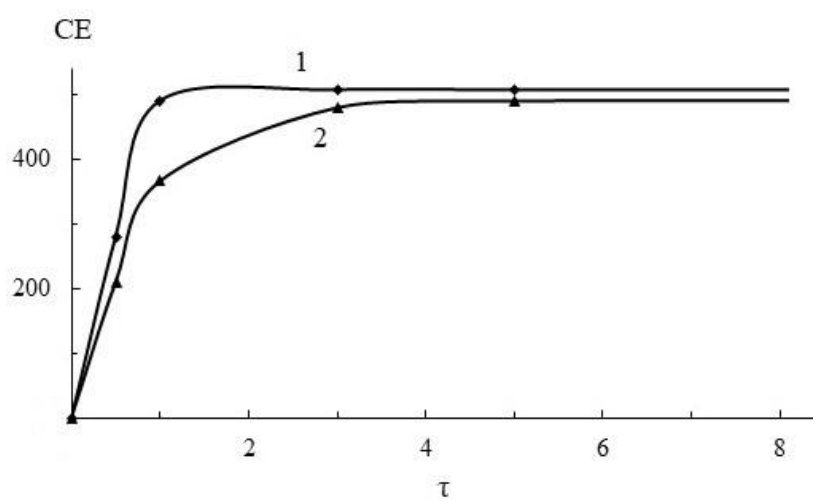

Figure 6: Sorption of strontium (II) ions by BA-ECH-PEI (1) and AECH-PEI (2) as a function of duration of its contact with $\mathrm{SrCl}_{2}$ solution $\left(\mathrm{c}_{\mathrm{Sr}}=2.015 \mathrm{~g} \cdot \mathrm{l}^{-1}, \mathrm{pH}=1.0\right)$

It has been established in [8] that the polymer complexing sorbents of various structure, which contain $-\mathrm{CH}_{2}-\mathrm{NH}-$ ion exchanging groups, more completely extract $\mathrm{Sr}^{2+}$ ions in acid mediums. The maximum performance of the sorbent, used in [18] for extraction of strontium ions, is $40.6 \mathrm{mg} \cdot \mathrm{g}^{-1}$. On the basis of experimental data, it has been established that the most promising for practical application are the sorbents with the best kinetic properties and maximum $S C$, which is $3.5-50.0 \mathrm{mg} \cdot \mathrm{g}^{-1}$, that is, by 50 times less than that of the synthesized ion exchangers characterized by the best kinetic properties.

\section{Conclusions}

1. The main physicochemical and thermal properties of the obtained sorbents have been studied. Their composition and structure are detected.

2. Sorption capacity of the synthesized anionites based on epoxy derivatives of aromatic amines and polyethylenimine with regard to strontium (II) ions has been studied. It has been established that they are characterized by high affinity to $\mathrm{Sr}^{2+}$ ions upon their extraction from individual model $\mathrm{SrCl}_{2}$ solutions.

3. It has been determined that the medium acidity in the range of $\mathrm{pH}=1.0-6.3$ exerts influence on sorption of strontium (II) ions. Maximum sorption is observed at $\mathrm{pH}=1.0$.

4. The obtained BA-ECH-PEI and A-ECH-PEI anionites are characterized by superior kinetic properties. Complete chemical equilibrium is achieved in 1 and $3 \mathrm{~h}$, respectively.

\section{Findings}

This work was supported by the Committee of Science, Ministry of Education and Science of the Republic of Kazakhstan, grant No. AP05131439: Synthesis and modification of nanostructured ion exchange membranes and development of innovative water treatment systems on their basis.

\section{Conflict of interests}

The authors confirm that the submitted data do not contain conflict of interest.

\section{Authors' contribution}

All authors of this study have a complete contribution for data collection, data analyses and manuscript writing.

\section{References}

1. Polyakova UV, Maslennikova TP, Sinel'shchikova OYu. Sorbtsiya ionov strontsiya na kalii-titanatnykh nanomaterialakh, poluchennykh $\mathrm{v}$ gidrotermal'nykh usloviyakh [Sorption of strontium ions on potassium titanium nanomaterials produced under hydrothermal conditions]. In: Proceedings, 16th Youth Scientific Conference, Institute of Silicate Chemistry, Russian Academy of Sciences: 3D printing of ceramic composites for structures operating under extreme loads. St. Petersburg: OOO Izdatel'stvo LEMA; 2017. p. 45-47.

2. Kitikova NV, Ivanets AI, Shashkova IL, Radkevich AV, Shemet LV, Zarubo AM. Fosfatnye sorbenty na osnove dolomita dlya izvlecheniya radionuklidov kobal'ta i strontsiya iz model'nykh rastvorov morskoi vody [Phosphate sorbents based on dolomite for extraction of cobalt and strontium radionuclides from model solutions of sea water]. Trudy Kol'skogo nauchnogo tsentra RAN. 2018; 9(21):279-285. Available from: https://doi.org/10.25702/KSC.23075252.2018.9.1.279-285

3. Ahmadpour A, Zabihi M, Tahmasbi M, Rohani Bastami T. Effect of adsorbents and chemical treatments on the removal of strontium from aqueous solutions. Journal of Hazardous Materials. 2010; 182(13):552-556. Available from: https://doi.org/10.1016/j.jhazmat.2010.06.067

4. Zuo R, Meng L, Guan X, Wang J, Yang J, Lin Y. Removal of strontium from aqueous solutions by acrylamide-modified attapulgite. Journal of Radioanalytical and Nuclear Chemistry. 2019; 319:1207-1217. Available from: https://doi.org/10.1007/s10967019-06414-y

5. Wang H, Wang XJ, Ma JX, Xia P, Zhao JF. Removal of cadmium (II) from aqueous solution: a comparative study of raw attapulgite clay and a reusable waste-struvite/attapulgite obtained from nutrient-rich wastewater. Journal of Hazardous Materials. 2017; 329:66-76. Available from: https://doi.org/10.1016/j.jhazmat.2017.01.025

6. Zhao Y, Shao ZY, Chen CL, Hu J, Chen HL. Effect of environmental conditions on the adsorption behavior of $\operatorname{Sr}(\mathrm{II})$ by Na-rectorite. Applied Clay Science. 2014; 87:1-6. Available from: https://doi.org/10.1016/j.clay.2013.11.021

7. Baccar R, Bouzid J, Feki M, Montiel A. Preparation of activated carbon from Tunisian olive-waste cakes and its application for adsorption of heavy metal ions. Journal of Hazardous Materials. 2009; 162:1522-1529. Available from: https://doi.org/10.1016/j.jhazmat.2008.06.041

8. Anikin VYu, Basargin NN, Tarasova OV, Rozovskii YuG. Sorbtsiya strontsiya (II) polimernymi kompleksoobrazuyushchimi sorbentami razlichnoi struktury [Strontium (II) sorption by complexing polymeric sorbents with various structures]. ZhNKh [Russian Journal of Inorganic Chemistry]. 2009; 54(9):1507-1511. Available from: https://doi.org/10.1134/S0036023609090289

9. Bhosle SM, Ponrathnam S, Tambe SS, Chavan NN. Adsorption of strontium (II) metal ions using phosphonate-functionalized polymer. Bulletin of Materials Science. 2016; 39:1541-1556. Available from: https://doi.org/10.1007/s12034-016-1295-7

10. Mayordomo $\mathrm{N}$, Alonso U, Missana T. Effects of $\gamma$-alumina nanoparticles on strontium sorption in smectite: Additive model approach. Applied Geochemistry. 2019; 100:121-130. Available from: https://doi.org/10.1016/j.apgeochem.2018.11.012

11. Ergozhin EE, Chalov TK, Kovrigina TV, Melnikov YeA, Nikitina AI. Izuchenie sorbtsionnoi sposobnosti sintezirovannykh anionitov na osnove anilina, epikhlorgidrina i nekotorykh poliaminov po otnosheniyu $\mathrm{k}$ ionam molibdena (VI) [Performance of anion exchangers based on aniline, epichlorohydrin, and polyamines in sorption of molybdenum (VI) ions]. ZhPKh [Russian Journal of Applied Chemistry]. 2017; 90(5):769-774. Available from: https://doi.org/10.1134/S1070427217050172 
12. Böcker J. Spektroskopie: Instrumentelle Analytik mit Atom- und Molekülspektrometrie. Würzburg: Vogel Buchverlag; 1997.

13. Ergozhin EE, Chalov TK, Kovrigina TV, Serikbaeva KT, Nikitina AI. Izvlechenie perrenat-ionov makrosetchatym anionitom na osnove epoksidirovannogo vinilovogo efira monoetanolamina, allilglitsidilovogo efira i polietilenimina [Recovery of perrhenate ions with a macrocellular anion exchanger based on epoxidized monoethanolamine vinyl ether, allyl glycidyl ether, and polyethyleneimine]. ZhPKh [Russian Journal of Applied Chemistry]. 2013; 86(10):1545-1548. Available from: https://doi.org/10.1134/S1070427213100121

14. Naushad M, Al-Othman ZA. A Book on Ion Exchange, Adsorption and Solvent Extraction. Nova Science Publishers, Inc.; 2013. 350 p.

15. Tulupov PE. Stoikost' ionoobmennykh materialov [Resistance of ion exchanging materials]. Moscow: Khimiya; 1984.

16. Chanda M. Plastics Technology Handbook. Boca Raton, FL: CRC Press; 2017. 1709 p.

17. Mel'nikov EA, Khakimbolatova KKh, Nikitina AI, Ergozhin EE, Chalov TK. Issledovanie termicheskoi ustoichivosti ionoobmennykh materialov na osnove epoksiaminov [Studying thermal stability of ion exchanging materials based on epoxy amines]. In: Cherezova EN, editor. Collection of works: Shkola nauchno-tekhnicheskogo tvorchestva i kontseptual'nogo proektirovaniya [School of R\&D creativity and conceptual design]. Kazan: Kazan National Research Technological University; 2012. p. 61-63.

18. Zhang L, Wei J, Zhao X, Li F, Jiang F, Zhang M. Strontium (II) adsorption on $\mathrm{Sb}(\mathrm{III}) / \mathrm{Sb}_{2} \mathrm{O}_{5}$. Chemical Engineering Journal. 2015; 267:245-252. Available

from:

https://doi.org/10.1016/j.cej.2014.11.124 